\title{
The expansion of exotic Chinook salmon (Oncorhynchus tshawytscha) in the extreme south of Patagonia: an environmental DNA approach
}

\author{
Cristina Fernanda Nardi (D) Daniel Alfredo Fernández (i) - Fabián Alberto Vanella • \\ Tomás Chalde $\mathbb{D}$
}

Received: 30 May 2018/ Accepted: 17 December 2018

(C) Springer Nature Switzerland AG 2019

\begin{abstract}
The ability to detect species at low densities, greatly improves the success of management action on alien invasive species and decreases their possible impact on ecosystems. In the last two decades, exotic Chinook salmon (Oncorhynchus tshawytscha) have established populations in both Pacific and Atlantic river basins of Patagonia. The last established populations have been reported in the extreme south of Patagonia, on the island of Tierra del Fuego (TDF). The relatively recent appearance of Chinook salmon in TDF and the great phenotypic
\end{abstract}

Electronic supplementary material The online version of this article (https://doi.org/10.1007/s10530-018-1908-8) contains supplementary material, which is available to authorized users.

C. F. Nardi · D. A. Fernández

Instituto de Ciencias Polares, Recursos Naturales y Ambientes, Universidad Nacional de Tierra del Fuego (ICPA-UNTDF), Fuegia Basket 251,

V9410BXE Ushuaia, Argentina

D. A. Fernández · F. A. Vanella · T. Chalde $(\bowtie)$ Laboratorio de Ecología, Fisiología y Evolución de Organismos Acuáticos, Centro Austral de Investigaciones Científicas (CADIC-CONICET), Bernardo Houssay 200, V9410BFD Ushuaia, Tierra del Fuego, Argentina e-mail: tomaschalde33@gmail.com

F. A. Vanella $\cdot$ T. Chalde

Extensión Áulica Ushuaia (UTN-FRRG), Facultad

Regional Río Grande, Universidad Tecnológica Nacional, Perito Moreno 1425, V9410KSS Ushuaia,

Tierra del Fuego, Argentina plasticity of this species, make it necessary to study their distribution and expansion as soon as possible, since they have the potential to negatively impact on native ecosystems. With the objective of knowing the current distribution status of exotic Chinook salmon in TDF, we optimized and implemented a detection method based on environmental DNA (eDNA). First, we designed Chinook salmon-specific primers, with no cross-amplification, using DNA from other species that are living at the same environment. Second, we validated the primers in situ by detecting Chinook salmon DNA from natural environments at the same time that we performed a conventional survey using an electrofishing survey method. Finally, we collected water samples from 10 river basins and one estuary within TDF and one river basin from Isla de los Estados (IE) and performed single-species real-time PCR assays. We were able to detect Chinook salmon DNA from 5 basins and from the estuary in TDF. These eDNA-based results allowed us to confirm the expansion of exotic Chinook salmon since they were first reported in TDF.

Keywords Non-native species - Alien invasive species - Salmonids · eDNA · South America - Tierra del Fuego 


\section{Introduction}

Alien invasive species (AIS) are one of the major causes of biodiversity loss and global homogenization (Vitousek et al. 1997; Ehrenfeld 2010). Once an AIS becomes established, costs of control can be extremely high and complete eradication is not always achieved (Dejean et al. 2012). In the early stages after their introduction, AIS often occur at low densities, making them hard to detect. If the detection method that is used is not sensitive enough, then detection may only be possible once the species is already well established (Myers et al. 2000). The ability to detect an AIS at low densities deeply determines the success of an eradication operation, decreases the costs of control and reduces its impact on ecosystems (Mehta et al. 2007).

Environmental DNA (eDNA) is a relatively new approach that is used to monitor the distribution of species. Using this method, it is possible to detect species without actually seeing or catching them (Herder et al. 2014; Taberlet et al. 2018). This method is particularly advantageous since it increases the chance of early detection of AIS and it has already been successfully applied in several groups of aquatic species, such as amphibians (Dejean et al. 2012), reptiles (Piaggio et al. 2014), crustaceans (Tréguier et al. 2014), and fish (Takahara et al. 2013; Fernandez et al. 2018).

The introduction of fish has been a common practice throughout the world, with sport fishing and aquaculture as the main objectives (Leprieur et al. 2008). In Patagonia, several salmonids that are native to the Northern Hemisphere, such as brown trout (Salmo trutta), rainbow trout (Oncorhynchus mykiss) and brook trout (Salvelinus fontinalis), have been introduced and successfully established almost a century ago (Pascual et al. 2007, 2009). In contrast, the Chinook salmon (Oncorhynchus tshawytscha) invasion occurred due to the practice of free-ranching and accidental escapes from aquaculture facilities in Chile (Soto et al. 2001; Correa and Moran 2017). It is known that there are several established Chinook salmon populations in Northern Patagonia $\left(39^{\circ} \mathrm{S}-\right.$ $51^{\circ} \mathrm{S}$ ) since 2000 (Correa and Gross 2008). In contrast, the presence of the first established population of this species in the extreme south of Patagonia $\left(54^{\circ} \mathrm{S}\right)$, on the Island of Tierra del Fuego (TDF), has been recently reported (Fernández et al. 2010). At the present time, two established populations have been described in TDF. One of the populations was characterized as a fall-run population at the Lapataia river (Fernández et al. 2010) and the other population was characterized as a spring-run population at the Grande river (Chalde et al. 2016). Nevertheless, according to Fernández et al. (2010), approximately 30 other rivers have the potential to be invaded by Chinook salmon.

The recent appearance of Chinook salmon on the island of TDF makes it necessary to study their distribution and expansion as soon as possible, since they have the potential to negatively impact on native ecosystems. For instance, trophic interactions have been observed between Chinook salmon and both freshwater and marine native species in Patagonia (Ciancio et al. 2008; Di Prinzio and Arismendi 2018). In addition, since Chinook salmon are an anadromous and semelparous species, they supply marine derived nutrients into rivers, disturbing natural cycles and balances (Soto et al. 2007; Arismendi and Soto 2012).

In this study, we optimized an eDNA-based method for improving detection and thus refining the known distribution of Chinook salmon in South Patagonia. Our work included: (1) designing of Chinook salmonspecific primers; (2) validation of the primers in silico, in vitro and in situ with the aim of testing their specificity and ability to amplify Chinook salmon DNA from water samples; (3) collection of water samples from river basins covering the four hydrological regions described in TDF; and (4) the detection of Chinook salmon DNA from environmental samples by real-time PCR. Additionally, we compared the eDNA-based results to historical captures of Chinook salmon in TDF.

\section{Materials and methods}

\section{Design of Chinook salmon primers}

We designed two sets of primers on the mitochondrial genome of Chinook salmon using Primer 3.0 software (Koressaar and Remm 2007; Untergasser et al. 2012) (See Online Resource 1). The first set was designed on the cytochrome oxidase subunit I gene (COI; Accession Number KU867892.1), being the COI Fw 5'agaaccatttgggtacatggga- $3^{\prime}$ and the COI Rv $5^{\prime}$-aagtaggcacgagtgtcaac $-3^{\prime}$. The second set was designed on a section that included the end of the D-loop region, and 
the tRNA-Phe and 12S rRNA genes (AN AF392054.1 966-1145): D-loop Fw 5'-cattttccegcctaaccac-3' and $12 \mathrm{~S} \mathrm{Rv} 5^{\prime}$-gcaggggattaagggcatcc- $3^{\prime}$. These primers were tested using the Oligo Analyzer 3.1 tool that is included on the Integrated DNA Technologies webpage (http://eu.idtdna.com/calc/analyzer) in order to check their functionality for real-time PCR assay.

\section{Validation of primers}

The validation of primers was achieved using in silico, in vitro and in situ analysis as proposed by Goldberg et al. (2016). First, an in silico analysis was performed using the primer BLAST tool of the National Center for Biotechnology Information Search (https://www. ncbi.nlm.nih.gov//tools/primer-blast/). There were three native species included in the analysis: puyen (Galaxias maculatus and G. platei) and lamprey (Geotria australis) and four exotic salmonids: Chinook salmon, rainbow trout, brown trout and brook trout; they corresponded to the overall fish species reported in the area (Cussac et al. 2016). Although not observed since reported by Moreno and Jara (1984), Aplochiton taeniatus and A. zebra were also added to the in silico analysis.

For in vitro analysis, total DNA was extracted from muscle of our target species and co-occurring nontarget species by the salting-out purification method (Miller et al. 1988). DNA samples were quantified using a Qubit 3.0 fluorimeter (Invitrogen, ThermoFisher Scientific) and DNA quality was assessed by amplifying the COI gene using universal primers reported by Ward et al. (2005) with modification, being the forward primer $5^{\prime}$-tcracyaaycayaaagayatyggcac- $3^{\prime}$ and the reverse primer $5^{\prime}$-takacytcwgggtgdccraaraayca- $3^{\prime}$. The limit of detection of target DNA was established by running a dilution series of a known amount of template (ranging from $2 \times 10^{-1}$ to $2 \times 10^{-6} \mathrm{ng} / \mu \mathrm{L}$ ). A dilution of $2 \times 10^{-5} \mathrm{ng} / \mu \mathrm{L}$ was used for target and non-target templates in the specificity analysis and four controls were established in order to check for cross-amplification (Fig. 1). The amplification reactions were performed in triplicate using real-time PCR and a StepOne ${ }^{\mathrm{TM}}$ real-time PCR system equipment (Applied Biosystems) in a total volume of $15 \mu \mathrm{L}$; including $1 \mathrm{X}$ iTaq SYBR Green supermix (Bio-Rad); $0.15 \mu \mathrm{M}$ of the COI primers or $0.45 \mu \mathrm{M}$ of D-loop and $12 \mathrm{~S}$ primers and $1 \mu \mathrm{L}$ of each template. When more than one template was added, the final volume was adjusted with distilled water. The PCR conditions included a touch-down step for increasing specificity as follows: $95^{\circ} \mathrm{C}$ for $5 \mathrm{~min}$ followed by a denaturation step at $94{ }^{\circ} \mathrm{C}$ for $15 \mathrm{~s}$, and an annealing/extension step at $65^{\circ} \mathrm{C}$ for $1 \mathrm{~min}$. During the first 10 cycles, the annealing temperature was decreased by $0.5{ }^{\circ} \mathrm{C}$ every cycle, followed by 30 additional cycles at $60{ }^{\circ} \mathrm{C}$. At the end of the amplification reaction, a melting curve from $60{ }^{\circ} \mathrm{C}$ to $95{ }^{\circ} \mathrm{C}$ at $0.3{ }^{\circ} \mathrm{C}$ increments was performed. A cycle threshold $(\mathrm{Ct})$ analysis was performed and PCR products were visualized in $2 \%$ low EEO agarose gels. The sequence from the specificity control was verified at the Macrogen Korea sequencing service.

Aquarium experiment and field sampling for validation of primers in situ

Juveniles of Chinook salmon were reared in a $100 \mathrm{~L}$ aquarium at $10{ }^{\circ} \mathrm{C}$. After 1 week, $1 \mathrm{~L}$ of water was collected. All aquarium equipment was sterilized by spraying with bleach solution (20\% v/v) and rinsed with distilled water prior to use. To confirm the absence of fish DNA in the aquariums prior to the experiment, $1 \mathrm{~L}$ of water was also taken before the introduction of fish. We obtained a unique melting curve using real-time PCR and the eDNA collected from the aquarium. The Tm was $\pm 0.03{ }^{\circ} \mathrm{C}$ in comparison to that obtained for the positive control.

For in situ validation, $1 \mathrm{~L}$ of water was collected on November 15th with sterile bottles from two sites separated from each other by $800 \mathrm{~m}$, in the Lapataia river at the TDF National Park. The downstream site was located just below the juvenile rearing area for Chinook salmon as described by Chalde and Fernández (2017). The upstream site was located in an area that it is known to be used only sporadically by Chinook migrants (Chalde and Fernández 2017). In addition, $1 \mathrm{~L}$ of water was collected on November 20th from a river where the target species is known to be absent (Lasifashaj up) (Fig. 2). After the water samples were taken, electrofishing surveys (LR-24 Electrofisher, Smith Root Inc, WA, USA) were performed in order to confirm the presence of Chinook salmon at these sites. 


\begin{tabular}{cccc}
\hline $\begin{array}{c}\text { No } \\
\text { Template } \\
\text { Control } \\
\text { (NTC) }\end{array}$ & $\begin{array}{c}\text { Positive } \\
\text { Control } \\
(+\mathbf{C})\end{array}$ & $\begin{array}{c}\text { Specificity } \\
\text { Control } \\
\text { (SC) }\end{array}$ & $\begin{array}{c}\text { Control for cross-reaction: } \\
\text { Non-Specific Control }\end{array}$ \\
\hline $\begin{array}{c}1 \mu 1 \text { of } \\
\text { distilled } \\
\text { water }\end{array}$ & $\begin{array}{c}1 \mu 1 \text { DNA of } \\
\text { target } \\
\text { species }\end{array}$ & $\begin{array}{c}1 \mu 1 \text { DNA of } \\
\text { each } \\
\text { species }\end{array}$ & $\begin{array}{c}1 \mu 1 \text { DNA of } \\
\text { each species; except } \\
\text { the target }\end{array}$ \\
\hline
\end{tabular}

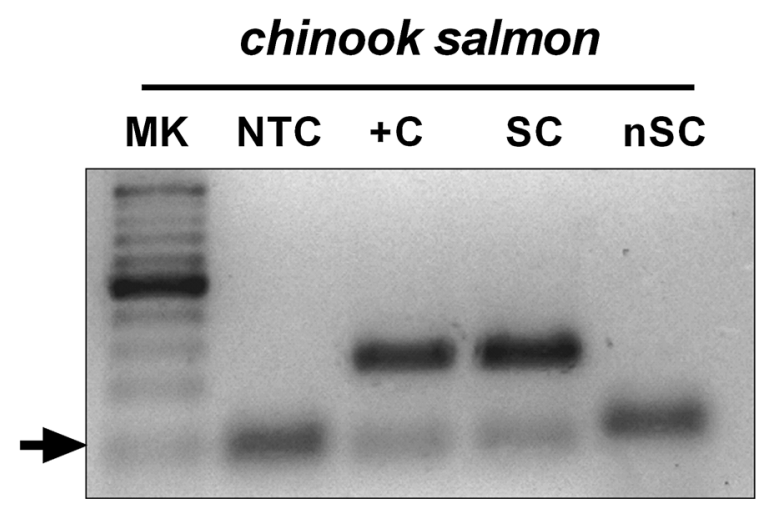

Fig. 1 Primers specificity analysis performed by real time PCR with Chinook salmon set of primers and target and non-target DNA as template/s. MK: mass molecular standard; the thick band corresponds to the $250 \mathrm{bp}$ amplicon. Arrow indicates the primer dimers

Study area and water sampling for distribution analysis of Chinook salmon

A total of 20 environmental water samples were collected using sterile bottles ( $1 \mathrm{~L}$ per site), following the procedure for avoiding contamination, as described by Carim et al. (2015) (Table 1 and Fig. 2). Sample sites were distributed along 13 streams (10 river basins) and 1 estuary bay, covering the four hydrological regions in TDF as described by Iturraspe and Urciuolo (2000). Samples were taken from the top $30 \mathrm{~cm}$ of the water column in wadeable run channel units. Water samples were maintained at $4-8{ }^{\circ} \mathrm{C}$ and filtered within the next $24 \mathrm{~h}$. Five of the river basins discharge into the Beagle Channel $\left(54.5^{\circ} \mathrm{S}\right)$ and another five of the river basins discharge into the Atlantic Ocean $\left(53.4^{\circ} \mathrm{S}-\right.$ $\left.54.5^{\circ} \mathrm{S}\right)$. The estuary is a small bay in the Beagle Channel where the Varela river and two small creeks discharge. In addition, five sites were sampled from IE. These were located on the same river basin, flowing to the south $\left(54.5^{\circ} \mathrm{S}\right)$, including one sampling point at the Villordo lake. TDF samples were taken during spring
2017 (October-November) and IE samples during summer 2017 (December).

eDNA extraction

Water samples were filtered using disposable sterile filter units of cellulose nitrate with $0.45-\mu \mathrm{m}$ pore size until the full volume passed through or the filter was clogged. Filters were stored individually at $-80{ }^{\circ} \mathrm{C}$ until DNA extraction. eDNA was extracted using QIAShredder and Qiagen's DNeasy Blood \& Tissue Kits (Qiagen GmbH, Hilden, Germany) following the manufacturer's protocol with minor modifications, according to Goldberg et al. (2011). One half of the filter was used for extraction and the remaining half was kept at $-80^{\circ} \mathrm{C}$. Final elutes were stored in 100 $\mu \mathrm{L}$ of $\mathrm{AE}$ buffer, included in the kit. In all cases, eDNA extractions were performed under sterile conditions, in a laboratory unit that was exposed periodically to UV-light and where no other tissue samples were manipulated. To ensure that the process was correct, $1 \mathrm{~L}$ milliQ water was filtrated and included in all eDNA analyses to confirm that contamination did 




Fig. 2 Estimated presence/non-detection of Chinook salmon presence and non-detection of Chinook salmon, respectively. (O. tshawytscha) in the study area based on the detection of Based on Iturraspe and Urciuolo (2000) environmental DNA (eDNA). Red and gray circles indicate

not occur during the filtration or the DNA extraction process.

eDNA analysis and amplification

Environmental samples were analyzed for the possible presence of inhibitors of the PCR reaction according to Herder et al. (2014). In briefly, $1 \mu \mathrm{L}$ of three different dilutions $(1: 10 ; 1: 20$ and $1: 40)$ of the eDNA samples and an internal positive control were mixed in a tube. A real-time PCR was performed in order to amplify the internal positive control (IPC). Samples were considered inhibition-free when the amplification plot of the IPC in the presence of the eDNA was comparable to that observed in the positive control (IPC without eDNA).

Since eDNA samples were highly diluted (up to 1:40), with respect to avoiding inhibition an amplification control, was also performed. For this, we designed a set of primers that amplify a fragment of 169 bp of the ribulose-1,5-bisphosphate carboxylase gene $(\mathrm{rcbl})$ of several diatoms inhabiting the area (Espinosa 2008); being the forward primer $5^{\prime}$-gtgaataccaccagaagcaaca- $3^{\prime}$ and the reverse primer $5^{\prime}$ - 
Table 1 Results of the eDNA-based method and historical data on detection of Chinook salmon. The sampling sites correspond to Tierra del Fuego and Isla de los Estados (IE)

\begin{tabular}{|c|c|c|c|c|c|c|}
\hline Site & Habitat & Position & Distance from mouth $(\mathrm{km})$ & Template dilution & eDNA detection & Historical records ${ }^{\mathrm{a}}$ \\
\hline Lapataia & River & $\begin{array}{l}54^{\circ} 50^{\prime} 37^{\prime \prime} \mathrm{S} \\
68^{\circ} 33^{\prime} 44^{\prime \prime} \mathrm{W}\end{array}$ & 0.5 & $1: 10$ & + & 3 \\
\hline Lasifashaj & River & $\begin{array}{l}54^{\circ} 52^{\prime} 22^{\prime \prime} \mathrm{S} \\
67^{\circ} 23^{\prime} 36^{\prime \prime} \mathrm{W}\end{array}$ & 3.0 & $1: 40$ & + & 0 \\
\hline Varela & River & $\begin{array}{l}54^{\circ} 52^{\prime} 31^{\prime \prime} \mathrm{S} \\
67^{\circ} 18^{\prime} 8^{\prime \prime} \mathrm{W}\end{array}$ & 2.0 & $1: 20$ & - & 0 \\
\hline Varela & Bay & $\begin{array}{l}54^{\circ} 52^{\prime} 13^{\prime \prime} \mathrm{S} \\
67^{\circ} 16^{\prime} 33^{\prime \prime} \mathrm{W}\end{array}$ & - & $1: 10$ & + & 2 \\
\hline Cambaceres & River & $\begin{array}{l}54^{\circ} 52^{\prime} 55^{\prime \prime} \mathrm{S} \\
67^{\circ} 14^{\prime} 20^{\prime \prime} \mathrm{W}\end{array}$ & 0.8 & $1: 20$ & + & 0 \\
\hline Moat & River & $\begin{array}{l}54^{\circ} 58^{\prime} 4^{\prime \prime} \mathrm{S} \\
66^{\circ} 44^{\prime} 30^{\prime \prime} \mathrm{W}\end{array}$ & 0.8 & $1: 20$ & - & 1 \\
\hline Irigoyen up & River & $\begin{array}{l}54^{\circ} 31^{\prime} 17^{\prime \prime} \mathrm{S} \\
66^{\circ} 22^{\prime} 52^{\prime \prime} \mathrm{W}\end{array}$ & 9.5 & $1: 20$ & + & 0 \\
\hline Irigoyen down & River & $\begin{array}{l}54^{\circ} 30^{\prime} 54^{\prime \prime} \mathrm{S} \\
66^{\circ} 17^{\prime} 33^{\prime \prime} \mathrm{W}\end{array}$ & 0.4 & $1: 10$ & + & 1 \\
\hline Pirinaica & River & $\begin{array}{l}54^{\circ} 14^{\prime} 50^{\prime \prime} \mathrm{S} \\
66^{\circ} 57^{\prime} 58^{\prime \prime} \mathrm{W}\end{array}$ & 11.5 & $1: 20$ & - & 0 \\
\hline Asturiana $^{\mathrm{b}}$ & River & $\begin{array}{l}54^{\circ} 15^{\prime} 20^{\prime \prime} \mathrm{S} \\
66^{\circ} 56^{\prime} 28^{\prime \prime} \mathrm{W}\end{array}$ & 12.8 & $1: 20$ & - & 0 \\
\hline Ewan & River & $\begin{array}{l}54^{\circ} 12^{\prime} 22^{\prime \prime} \mathrm{S} \\
67^{\circ} 12^{\prime} 55^{\prime \prime} \mathrm{W}\end{array}$ & 20.5 & $1: 10$ & - & 0 \\
\hline Grande & River & $\begin{array}{l}53^{\circ} 50^{\prime} 10^{\prime \prime} \mathrm{S} \\
67^{\circ} 47^{\prime} 34^{\prime \prime} \mathrm{W}\end{array}$ & 14.7 & $1: 20$ & + & 3 \\
\hline Candelaria $^{c}$ & River & $\begin{array}{l}53^{\circ} 51^{\prime} 49^{\prime \prime} \mathrm{S} \\
67^{\circ} 50^{\prime} 29^{\prime \prime} \mathrm{W}\end{array}$ & 15.5 & $1: 40$ & + & 2 \\
\hline Rasmussen $^{\mathrm{c}}$ & River & $\begin{array}{l}53^{\circ} 54^{\prime} 33^{\prime \prime} \mathrm{S} \\
68^{\circ} 28^{\prime} 10^{\prime \prime} \mathrm{W}\end{array}$ & 77.5 & $1: 10$ & + & 2 \\
\hline Chico & River & $\begin{array}{l}53^{\circ} 40^{\prime} 25^{\prime \prime} \mathrm{S} \\
67^{\circ} 56^{\prime} 7^{\prime \prime} \mathrm{W}\end{array}$ & 10.2 & $1: 40$ & - & 1 \\
\hline Villordo $^{\mathrm{d}}$ & Lake & $\begin{array}{l}54^{\circ} 49^{\prime} 51^{\prime \prime} \mathrm{S} \\
64^{\circ} 38^{\prime} 55^{\prime \prime} \mathrm{W}\end{array}$ & 3.0 & $1: 20$ & - & NPD \\
\hline IE $1^{\mathrm{d}}$ & Creek & $\begin{array}{l}54^{\circ} 50^{\prime} 7^{\prime \prime} \mathrm{S} \\
64^{\circ} 38^{\prime} 34^{\prime \prime} \mathrm{W}\end{array}$ & 0.1 & $1: 20$ & - & NPD \\
\hline IE $2^{\mathrm{d}}$ & Creek & $\begin{array}{l}54^{\circ} 50^{\prime} 27^{\prime \prime} \mathrm{S} \\
64^{\circ} 38^{\prime} 54^{\prime \prime} \mathrm{W}\end{array}$ & 1.7 & $1: 20$ & - & NPD \\
\hline IE $3^{\mathrm{d}}$ & Creek & $\begin{array}{l}54^{\circ} 50^{\prime} 35^{\prime \prime} \mathrm{S} \\
64^{\circ} 38^{\prime} 34^{\prime \prime} \mathrm{W}\end{array}$ & 0.4 & $1: 20$ & - & NPD \\
\hline $\operatorname{IE~} 4^{\mathrm{d}}$ & Creek & $\begin{array}{l}54^{\circ} 50^{\prime} 35^{\prime \prime} \mathrm{S} \\
64^{\circ} 38^{\prime} 59^{\prime \prime} \mathrm{W}\end{array}$ & 1.4 & $1: 20$ & - & NPD \\
\hline
\end{tabular}

NPD no previous data

${ }^{a}$ Data recorded since 2006 by electrofishing, seine net, gill net, direct observation and angler fishing. 0: not observed; 1: single adult; 2: juveniles; 3 : spawning adults and juveniles

${ }^{\mathrm{b}}$ Tributary of Pirinaica river

${ }^{\mathrm{c}}$ Tributary of Grande river

${ }^{\mathrm{d}}$ Same basin 
cgctggtacagttgttggtaaa- $3^{\prime}$. The amplification reaction was performed in a total volume of $15 \mu \mathrm{L}$, including $1 \mathrm{X}$ iTaq SYBR Green supermix (Bio-Rad); $0.5 \mu \mathrm{M}$ of each primer and $1 \mu \mathrm{L}$ of diluted eDNA. Cycling conditions included a first denaturation step at $95{ }^{\circ} \mathrm{C}$ for $10 \mathrm{~min}$ and 40 cycles of a denaturation step at $95{ }^{\circ} \mathrm{C}$ for $15 \mathrm{~s}$ and an annealing/extension step at $60{ }^{\circ} \mathrm{C}$ for $1 \mathrm{~min}$.

For the amplification of the environmental samples, a five-point standard calibration curve was performed with Chinook salmon DNA as template, including a serial dilution from 0.2 to $2 \times 10^{-5} \mathrm{ng} / \mu \mathrm{L}$ to estimate the amplification efficiency of the primer pair. The standard calibration curve fitted the equation $\mathrm{y}=-3.721 \mathrm{x}+18.851, \quad \mathrm{R}^{2}=0.978$. Primers efficiency was $85-87 \%$. Conditions of real-time PCR reaction were as previously described for this set of primers with the exception that 35 cycles were used when annealing temperature reached $60{ }^{\circ} \mathrm{C}$. Each reaction was performed in a quintupled manner, including a negative water control in each run. One micro liter of the diluted environmental sample was added as template (Table 1). Amplification of at least two of the real-time PCR replicates, accompanied by a melting curve that is consistent with Chinook salmon DNA $\left(\mathrm{Tm}=78.58-78.88^{\circ} \mathrm{C}\right)$ and sequencing at the Macrogen Korea service, were required in order to identify a positive detection of the species. Furthermore, every positive environmental sequence was matched against the nucleotide database of the National Centre for Biotechnology Information (NCBI, http://www. ncbi.nlm.nih.gov/) using BLASTn (Basic Local Alignment Search Tool) to verify the species specificity. After obtaining Chinook salmon as a complete match, two additional species matched with $96 \%$ of sequence identity: Oncorhynchus kisutch and $O$. masou. In order to corroborate that the environmental amplicons did indeed correspond to Chinook salmon, an alignment was performed between the environmental amplicons and the sequence of the COI gene of the target and the two additional species (Online Resource 2). Those positions that matched with the target, but were different in the $O$. kisutch and $O$. masou, were corroborated by analyzing each chromatogram.

\section{Results}

Chinook salmon primers design and validation

Two sets of primers were designed and analyzed for specific Chinook salmon amplification. The target regions were selected after performing an alignment between Chinook salmon and rainbow trout mitochondrion genomes (both Oncorhynchus) (See Online Resource 1). In order to assess the reliability and specificity of the primers, in silico, in vitro and in situ analyses were performed in accordance with Goldberg et al. (2016). Even though two set of primers were designed, only the specific primer set that was designed on the COI gene was further used to analyze the distribution of Chinook salmon, since it passed all the validation steps. The alternative set of primers ( $\mathrm{Fw}$ D-loop, Rv 12S) failed at the in situ validation step (See Online Resource 3).

In silico analysis

A primer-BLAST search was conducted with the COI primers and this showed a $100 \%$ identity with Chinook salmon, amplifying a $120 \mathrm{bp}$ fragment. Although primers showed partial alignment with lamprey mitochondrion genome, there were five miss-matches at the forward primer, including one at the $3^{\prime}$ end, and three additional miss matches at the reverse primer.

In vitro analysis

A Chinook salmon COI primer pair was tested in vitro against tissue samples of all the co-occurring nontarget fish species, with no false positives due to crossspecies amplification. Figure 1 shows the four controls performed and the $120 \mathrm{bp}$ amplified band obtained in both cases: when the only template was Chinook salmon DNA $(+\mathrm{C})$ and when a mix of all templates was added to the tube (specificity control; SC). No amplification was observed in the nonspecific control (nSC), where all DNAs were present except for the target DNA. The SC amplicon was sequenced and corresponded to a Chinook salmon COI sequence with a $99 \%$ certainty of identity. No significant interferences at the $\mathrm{Ct}$ values were observed when all the DNAs were present in comparison to the $\mathrm{Ct}$ values obtained in the $+\mathrm{C}$. 
In situ analysis

COI primers passed the in situ validation step since we detected Chinook salmon DNA in the downstream site of the Lapataia river, and we also observed the target species after the electrofishing survey. In the upstream site, Chinook salmon were only detected by eDNA. Finally, In Lasifashaj up river, no detection of the species was observed by either of the two methods. The latter site is not accessible to Chinook salmon due to a waterfall that prevents access by this species. All positives detections were corroborated by sequencing.

Environmental DNA amplification control

A total of 20 water samples were collected from TDF and Isla de los Estados (IE). These environmental samples were analyzed for the possible presence of inhibitors of the PCR reaction and some of the samples were highly diluted in order to overcome inhibition (Table 1). For this reason, we established an additional control that aimed to know whether the DNA of the diluted samples was still functional. This control consisted in the amplification of a fragment of the ribulose-1,5-bisphosphate carboxylase gene (rcbl) of several diatoms that are abundant in freshwater and brackish environments in TDF (Espinosa 2008) and IE (Ponce and Fernández 2014). Every diluted environmental sample was subjected to this control, and only samples with no inhibition signs and that were positive for rcbl amplification were further used for Chinook salmon presence/non-detection analysis.

Chinook salmon detection and distribution analysis

We detected Chinook salmon DNA at 9 of the 20 sites that were sampled. Based on our results, we present a plot of the distribution of Chinook salmon in our study area (Fig. 2). The 9 positive sites correspond to three river basins flowing into the Beagle Channel (Lapataia, Lasifashaj and Cambaceres), two river basins flowing into the Atlantic Ocean (Irigoyen and Grande), and one estuary (Varela Bay). Chinook salmon DNA was also detected in two tributaries of Grande river: Candelaria and Rasmussen. The five sites sampled at IE were negative for the presence of Chinook salmon. All positive sequences were confirmed as being Chinook salmon.

\section{Discussion}

We optimized a method for determining the presence of exotic Chinook salmon based on the detection of eDNA in water samples. For this, we performed a species-specific real-time PCR assay by targeting a $120 \mathrm{bp}$ sequence of the COI region of Chinook salmon. This region has been targeted and sequenced for a wide range of organisms for DNA barcoding (Hebert et al. 2003), including salmon and trout species (Oncorhynchus and Salmo) (Rasmussen et al. 2009). In addition, the COI region has been widely used for detecting fish species by using eDNA (Dougherty et al. 2016; Laramie et al. 2015; Atkinson et al. 2018). There are previous studies that successfully designed eDNA-based assays to detect Chinook salmon by using real-time PCR (Brandl et al. 2015; Laramie et al. 2015). However, eDNA-based assays should be designed and tested for every application in a defined geographic area, thereby considering the closely-related, co-occurring species whose DNA may be present in the environmental samples (Goldberg et al. 2016).

A critical issue when optimizing this eDNA-based method was the detection of inhibitors of the PCR reaction in the environmental samples. These inhibitors are usually co-extracted with the eDNA (McKee et al. 2015) and they interact with the PCR by binding to DNA (humic acid), or they prohibit the binding of DNA polymerase (tannins) (Opel et al. 2010). PCR inhibitors may result in false-negative results, thus their presence should be investigated. Here, we observed that diluting the environmental samples was effective with respect to overcoming inhibition, as previously reported (Goldberg et al. 2013; Biggs et al. 2015; McKee et al. 2015). However, in most of the reported eDNA studies, the amounts of environmental sample used as template for the PCR assay ranged from 1 to $10 \mu \mathrm{L}$ of the stock eDNA (Rees et al. 2014), while we used higher dilutions of eDNA as template (up to $1 \mu \mathrm{L}$ of 1:40; Table 1 ). Thus, in order to avoid false negatives because of excessive dilution, we developed an eDNA amplification control by detecting a fragment of the rcbl gene of common diatoms at the area. This additional control allowed us to suppose that non-detection results were not due to excessive dilution of the environmental DNA.

In this work, 20 sites were sampled within TDF and IE. Table 1 summarizes the eDNA-based results 
obtained here and also includes historical detections of Chinook salmon by traditional methods since the beginning of the invasion, 12 years ago. We detected Chinook salmon DNA in environmental samples from rivers where the species had been previously reported and also from rivers with no previous data on Chinook salmon presence (Table 1). Lapataia and Grande basins were positive for eDNA Chinook salmon detection, which is in concordance with previous data regarding the establishment of reproductive populations at these sites (Fernández et al. 2010; Chalde et al. 2016). In addition, there have been proven reports of Chinook salmon that were captured by anglers in Moat river and Chico river. However, our results showed "non-detection" of this species by eDNA in both sites. This could be explained if we considered the fact that those previous reports correspond to a single specimen that was captured in each of these rivers since 2006. In this sense, it is probable that the individuals that were observed may have been Chinook salmon that were sporadically passing through those sites.

The eDNA approach developed here provides additional data on the presence of Chinook salmon in sites where they have never been reported before (Lasifashaj and Cambaceres rivers and Varela Bay) (Table 1). Previous reports propose that Chinook salmon established fall-run populations in basins flowing into the Beagle Channel (Fernández et al. 2010; Chalde and Fernández 2017). Taking this into account, we suggest that the Chinook salmon DNA detected in Lasifashaj and Cambaceres rivers would belong to juvenile fish, since water samples were taken during the spring, when fall-run adults should not be at the river. Therefore, future surveys should focus on these rivers in order to confirm spawning activity.

The establishment of a self-sustaining population is an important factor in assessing the biological impacts of the presence of exotic species (Naylor et al. 2005). Thus, it is critical to determine whether the detected DNA corresponds to juveniles or adults. This is not possible to achieve by eDNA-based methods, since there are no differences in genetic composition at different life stages. However, eDNA-based techniques could be used as a relatively quick and inexpensive tool for generating data on a species presence and distribution at large and/or inaccessible sampling areas, since water sampling requires basic equipment (plastic bottle, wader and gloves) and is easy to carry out. As an example, the cost per eDNA sample in Argentina ranges between USD 18 and USD 20 , including the sterile bottle, the filter, and both kits for DNA extraction. Thus, the eDNA technique would be a useful tool for surveying aquatic systems thoroughly. Then, according to the results obtained, surveys with complementary techniques could be performed at specific locations (Rees et al. 2014), as we propose here for Lasifashaj and Cambaceres rivers.

Basins in TDF may be classified into four types based on vegetation, hydrological homogeneity and geomorphological climatic factors: basins of the steppe, transition basins, mountain range basins and basins of peatland (Iturraspe and Urciuolo 2000). All sites that were sampled in this work to determine the presence of Chinook salmon comprise the four types of basins that were previously described. Thus, it can be observed that the expansion of Chinook salmon has reached several basins of the mountain range as well as those basins of the transition type (Fig. 2). It is known that Chinook salmon show significant phenotypic plasticity, which allows this species to rapidly adapt to different environments (Healey 1991). This would be in agreement with the expansion of Chinook salmon that was observed in this work.

Isla de los Estados is a protected area that is separated, by a distance of $30 \mathrm{~km}$ from the southeast of the TDF Island, by the Le Maire Strait and is considered one of the most inhospitable islands in the world (Ponce and Fernández 2014). There is only one report of fish distribution in IE, where the author describes the puyen as the single species found on the island (Gosztonyi 1970). It is noteworthy that even though non-detection of Chinook salmon DNA was achieved, to our knowledge this is the first effort made to study the presence of fish in IE since then.

In conclusion, the eDNA-based method that is optimized in the present study, allowed us to develop an updated Chinook salmon distribution map that shows an expansive behavior of this species since it was reported (Fernández et al. 2010; Chalde and Fernández 2017). Additionally, this eDNA technique could be used to monitor the expansion of Chinook salmon in southern Patagonia and also to determine the current state of invasion of this species in northern Patagonia. However, since the COI primers validated here partially match with two additional species of the Oncorhynchus genus; the environmental amplicons should be sequenced to confirm the species. This is 
particularly important in northern Patagonia, where $O$. masou has been reported (Pascual et al. 2002).

Acknowledgements This work was funded by Ministerio de Educación de Argentina (SPU-VT12-UNTF5286), Universidad Nacional de Tierra del Fuego (PID-UNTDF B 16), Agencia Nacional de Promoción Científica y Tecnológica (PICT 0759-2015) and Consejo Nacional de Investigaciones Científicas y Técnicas (PIP 440). The authors thank to Javier Rojo, Sebastián Poljak and Miguel Casalinuovo for their valuable assistance in field sampling as well as Carolina Camilion and Noelia Paredes for their laboratory technical assistance.

\section{References}

Arismendi I, Soto D (2012) Are salmon-derived nutrients being incorporated in food webs of invaded streams? Evidence from southern Chile. Knowl Manag Aquat Ecosyst 405:01

Atkinson S, Carlsson JEL, Ball B, Egan D, Kelly Quinn M, Whelan K, Carlsson J (2018) A quantitative PCR based environmental DNA assay for detecting Atlantic salmon (Salmo salar L.). Aquat Conserv 28:1-6

Biggs J, Ewald N, Valentini A, Gaboriaud C, Dejean T, Griffiths RA, Foster J, Wilkinson JW, Arnell A, Brotherton P, Williams P, Dunn F (2015) Using eDNA to develop a national citizen science-based monitoring programme for the great crested newt (Triturus cristatus). Biol Conserv 183:19-28

Brandl S, Schumer G, Schreier BM, Conrad JL, May B, Baerwald MR (2015) Ten real-time PCR assays for detection of fish predation at the community level in the San Francisco Estuary-Delta. Mol Ecol Resour 15:278-284

Carim KJ, Padgett-Stewart TM, Wilcox TM, Young MK, McKelvey K, Schwartz M (2015) Protocol for collecting eDNA samples from streams. General technical report, RMRS-GTR-355. U.S. Department of Agriculture, Forest Service, Rocky Mountain Research Station, Fort Collins, $\mathrm{CO}$

Chalde T, Fernández DA (2017) Early migration and estuary stopover of introduced Chinook salmon population in the Lapataia river basin, southern Tierra del Fuego Island. Estuar Coast Shelf Sci 199:49-58

Chalde T, Casalinuovo M, Rojo J, Villatarco P, Boy C, Lesta S, Fernández DA (2016) New establishment of a Chinook salmon (Oncorhynchus tshawytscha) population in the extreme South of Patagonia. Dissertation, freshwater invasive species, Buenos Aires, Argentina

Ciancio J, Pascual MA, Botto F, Frere E, Iribarne O (2008) Trophic relationships of exotic anadromous salmonids in the southern Patagonian shelf as inferred from stable isotopes. Limnol Oceanogr 53:788-798

Correa C, Gross M (2008) Chinook salmon invade southern South America. Biol Invasions 10:615-639

Correa C, Moran P (2017) Polyphyletic ancestry of expanding Patagonian Chinook salmon populations. Sci Rep 7:14338

Cussac VE, Habit E, Ciancio J, Battini MA, Riva Rossi C, Barriga JP, Baigún C, Crichigno S (2016) Freshwater fishes of Patagonia: conservation and fisheries. J Fish Biol 89:1068-1097

Dejean T, Valentini A, Miquel C, Taberlet P, Bellemain E, Miaud C (2012) Improved detection of an alien invasive species through environmental DNA barcoding: the example of the American bullfrog Lithobates catesbeianus. J Appl Ecol 49:953-959

Di Prinzio CY, Arismendi I (2018) Early development and diets of non-native juvenile Chinook Salmon (Oncorhynchus tshawytscha) in an invaded river of Patagonia, southern South America. Austral Ecol. https://doi.org/10.1111/aec. 12597

Dougherty MM, Larson ER, Renshaw MA, Gantz C, Egan SP, Erickson DM, Lodge DM (2016) Environmental DNA (eDNA) detects the invasive rusty crayfish Orconectes rusticus at low abundances. J Appl Ecol 53:722-732

Ehrenfeld JG (2010) Ecosystem consequences of biological invasions. Annu Rev Ecol Evol Syst 41:59-80

Espinosa MA (2008) Diatoms from Patagonia and Tierra del Fuego. Dev Quat Sci 11:383-392

Fernandez S, Sandin M, Beaulieu PG, Clusa L, Martinez JL, Ardura A, García-Vázquez E (2018) Environmental DNA for freshwater fish monitoring: insights for conservation within a protected area. PeerJ 6:e4486

Fernández DA, Ciancio J, Ceballos S, Riva-Rossi C, Pascual M (2010) Chinook salmon (Oncorhynchus tshawytscha, Walbaum 1792) in the Beagle Channel, Tierra del Fuego: the onset of an invasion. Biol Invasions 12:2991-2997

Goldberg CS, Pilliod DS, Arkle RS, Waits LP (2011) Molecular detection of vertebrates in stream water: a demonstration using rocky mountain tailed frogs and Idaho giant salamanders. PLoS ONE 6:e22746

Goldberg CS, Sepulveda A, Ray A, Baumgardt J, Waits LP (2013) Environmental DNA as a new method for early detection of New Zealand mudsnails (Potamopyrgus antipodarum). Freshw Sci 32:792-800

Goldberg CS, Turner CR, Deiner K et al (2016) Critical considerations for the application of environmental DNA methods to detect aquatic species. Methods Ecol Evol. https://doi.org/10.1111/2041-210X.12595

Gosztonyi AE (1970) Los peces de la expedición científica a la Isla de los Estados, Argentina (noviembre-diciembre 1967). Physis 30:173-180

Healey MC (1991) Life history of Chinook salmon (Oncorhynchus tshawytscha). In: Groot GC, Margolis L (eds) Pacific salmon life histories. University of British Columbia Press, Vancouver, pp 311-394

Hebert PD, Cywinska A, Ball SL, de Waard JR (2003) Biological identifications through DNA barcodes. Proc Biol Sci 270:313-321

Herder JE, Valentini A, Bellemain E, Dejean T, van Delft J, Thomsen P, Taberlet P (2014) Environmental DNA: a review of the possible applications for the detection of (invasive) species. Stichting RAVON, Nijmegen. Report 2013-104

Iturraspe R, Urciuolo A (2000) Clasificación y caracterización de las cuencas hídricas de Tierra del Fuego. Dissertation, XVIII Congreso Nacional del Agua, Santiago del Estero, Argentina 
Koressaar T, Remm M (2007) Enhancements and modifications of primer design program Primer3. Bioinformatics 23:1289-1291

Laramie MB, Pilliod DS, Goldberg CS (2015) Characterizing the distribution of an endangered salmonid using environmental DNA analysis. Biol Conserv 183:29-37

Leprieur F, Beauchard O, Blanchet S, Oberdorff T, Brosse S (2008) Fish invasions in the world's river systems: when natural processes are blurred by human activities. PLoS Biol 6:404-410

McKee AM, Spear AF, Pierson TW (2015) The effect of dilution and the use of a post-extraction nucleic acid purification column on the accuracy, precision, and inhibition of environmental DNA samples. Biol Conserv 183:70-76

Mehta SV, Haight RG, Homans FR, Polasky S, Venette RC (2007) Optimal detection and control strategies for invasive species management. Ecol Econ 61:237-245

Miller SA, Dykes D, Polesky H (1988) A simple salting out procedure for extracting DNA from human nucleated cells. Nucleic Acids Res 16:12-15

Moreno CA, Jara HF (1984) Ecological studies on fish fauna associated with Macrocystis pyrifera belts in the south of Fueguian Islands, Chile. Mar Ecol Prog Ser 15:99-107

Myers JH, Simberloff D, Kuris AM, Carey JR (2000) Eradication revisited: dealing with exotic species. Trends Ecol Evol 15:316-320

Naylor R, Hindar K, Fleming IA, Goldburg R, Williams S, Volpe J, Whoriskey F, Eagle J, Kelso D, Mangel M (2005) Fugitive salmon: assessing the risks of escaped fish from net-pen aquaculture. Bioscience 55:427-437

Opel KL, Chung D, McCord BR (2010) A study of PCR inhibition mechanisms using real time PCR. Forensic Sci 55:25-33

Pascual MA, Macchi P, Urbanski J, Marcos F, Riva Rossi C, Novara M, Dell'Arciprete P (2002) Evaluating potential effects of exotic freshwater fish from incomplete species presence-absence data. Biol Invasions 4:101-113

Pascual MA, Cussac V, Dyer B, Soto D, Vigliano P, Ortubay S, Macchi P (2007) Freshwater fishes of Patagonia in the 21st century after a hundred years of human settlement, species introductions, and environmental change. Aquat Ecosyst Health Manag 10:212-227

Pascual MA, Lancelotti JL, Ernst B, Ciancio JE, Aedo E, García-Asorey M (2009) Scale, connectivity, and incentives in the introduction and management of non-native species: the case of exotic salmonids in Patagonia. Front Ecol Environ 7:533-540

Piaggio AJ, Engeman RM, Hopken MW, Humphrey JS, Keacher KL, Bruce WE, Avery ML (2014) Detecting an elusive invasive species: a diagnostic PCR to detect Burmese python in Florida waters and an assessment of persistence of environmental DNA. Mol Ecol Resour 14:374-380

Ponce J, Fernández M (2014) Climatic and environmental history of Isla de los Estados. Springer, Berlin

Rasmussen RS, Morrissey MT, Hebert PDN (2009) DNA barcoding of commercially important salmon and trout species Oncorhynchus and Salmo) from North America. J Agric Food Chem 57:8379-8385

Rees H, Maddison B, Middleditch D, Patmore J, Gough K (2014) The detection of aquatic animal species using environmental DNA: a review of eDNA as a survey tool in ecology. J Appl Ecol 51:1450-1459

Soto D, Jara F, Moreno C (2001) Escaped salmon in the inner seas, southern Chile: facing ecological and social conflicts. Ecol Appl 11:1750-1762

Soto D, Arismendi I, Di Prinzio C, Jara F (2007) Establishment of Chinook salmon (Oncorhynchus tshawytscha) in Pacific basins of southern South America and its potential ecosystem implications. Rev Chil Hist Nat 80:81-98

Taberlet P, Bonin A, Zinger L, Coissac E (2018) Environmental DNA: for biodiversity research and monitoring. Oxford University Press, Oxford, p 272

Takahara T, Minamoto T, Doi H (2013) Using environmental DNA to estimate the distribution of an invasive fish species in ponds. PLoS ONE 8:e56584

Tréguier A, Paillisson JM, Dejean T, Valentini A, Schlaepfer M, Roussel JM (2014) Environmental DNA surveillance for invertebrate species: advantages and technical limitations to detect invasive crayfish Procambarus clarkii in freshwater ponds. J Appl Ecol 51:871-879

Untergasser A, Cutcutache I, Koressaar T, Ye J, Faircloth BC, Remm M, Rozen SG (2012) Primer3: new capabilities and interfaces. Nucleic Acids Res 40:e115

Vitousek PM, D'antonio CM, Loope LL, Rejmanek M, Westbrooks R (1997) Introduced species: a significant component of human-caused global change. N Z J Ecol 21:1-16

Ward RD, Zemlak TS, Innes BH, Last PR, Hebert PDN (2005) DNA barcoding Australia's fish species. Philos Trans R Soc Lond B Biol Sci 360:1847-1857 